\title{
Comparison between Sport Massage and Aquatic Exercise to Decrease The Level of Lactic Acid in Students of Universitas Negeri Jakarta
}

\begin{tabular}{|c|c|}
\hline & \\
$1^{\text {st }}$ Kuswahyudi & $2^{\text {nd }}$ Syefrina Salsabila \\
Faculty of Sports Science & Faculty of Sports Science \\
Universitas Negeri Jakarta, & Universitas Negeri Jakarta, \\
Jakarta Timur, Indonesia & Jakarta Timur, Indonesia \\
kuswahyudi@unj.ac.id & $\underline{\text { kuswahyudi@unj.ac.id }}$ \\
\hline
\end{tabular}

\begin{abstract}
This study aims to determine how much the ratio between sport massage and aquatic exercise to decrease lactic acid levels in students of UniversitasNegeri Jakarta. This research was conducted at GelanggangOlahragaRawamangun in December 2017. The method used is the experiment method "One Group Pre-test and Post-test Design". Samples of 20 people from the population of 100 people taken with purposive sampling technique. Data analysis technique used is t-test at significant level $\alpha=$ 0.05 analysis technique started by counting t-value to compare with t-table value at $5 \%$ significant level. From the final test data of sports massage and aquatic exercise, the standard difference between two mean $(\mathrm{SEmxmy})=\mathbf{0 . 8 1}$, the value becomes $\mathrm{t}$-value obtained $=$ 4.303. Then the result of the calculation is tested with the table on degrees of freedom $(\mathrm{dk})=(\mathrm{N} 1+\mathrm{N} 2)-2=$ $(20+20)-2$ and the 0.05 confidence level obtained the critical value $t$-table 2.021 ( $t$-value $=4.303>t$-table $=$ 2.021). The final conclusion obtained in this study is sport massage gives a greater influence on the decrease in lactic acid levels than aquatic exercise after recovery for 30 minutes.
\end{abstract} acid

Keywords: sport massage, aquatic exercise, lactic

\section{INTRODUCTION}

Exercise is very beneficial for health. By exercising the body's metabolism becomes increased so that the distribution and absorption of nutrients in the body becomes more effective and efficient.
Exercise is also a very good activity if it's done regularly, which is always done by sports students. In everyday life, sports students have so many physical activities, in the room they have to follow the lectures and outdoors they also have to follow the activities of the sport that they choose, because it is also included in the part of the lecture.

With so much activity, sports students should pay attention to a balance between lectures, exercises and physical condition recovery, in this case, the recovery of the condition is very important in maintaining one's physical condition in order to always be in optimal physical condition. Good recovery should be done immediately after completion of physical activity or heavy exercise.

Not many students know about the importance of recovery or recovery to reduce lactic acid after exercise, in this case as sports students must understand and apply recovery methods so that they do not experience prolonged fatigue and the physical condition will always be well preserved. This study is one of the efforts to find a comparison and effectiveness for a process of recovery of physical condition in terms of decreasing lactic acid levels [3].

Recovery should be done immediately when the condition of the body is exhausted or in other words experiencing buildup of lactic acid, this is done to 
make the lactic acid that accumulated immediately reduced and will accelerate the recovery process next. Recovery is divided into two types: active recovery and passive recovery [8].

Active Recovery is a recovery performed by moving or in the form of active movements performed with mild intensity but in a certain period of time such as jogging, cycling and swimming, with the movements or activities will make the blood circulation becomes smooth, which will be helps in the process of lactic acid replacement by the blood circulation to be brought to the liver and converted back into energy. In this research that will be done is the method of aquatic exercise, which is recovery with active movements in the water but with a mild intensity [6]. The general characteristic of aquatic exercise is: density, buoyancy, hidrostatic pressure, viscosity, and hydromechanics [9].

Here are the method of aquatic exercise used in this study:

- Water walking or jogging

- Forward and side lunges

- One leg balance

- Side stepping

- Hip kickers at pool wall

- Pool plank

- Carioca

- Rotational wake

- Push ups

- Standing knee lift

Recovery passive is a recovery performed without physical activity, which means that only by silence of the body it will recharge lost oxygen reserves after physical activity, oxygen will be used for lactic acid oxidation process which will convert lactic acid back into energy. In passive recovery thewriter use method of sport massage. Which means patients or athletes who have been doing physical activity get the treatment of sports massage where the patient did not do any physical activity [5].

Sport Massage is a very valuable element in exercises for athletes but for someone who is not an athlete is also useful to maintain and restore a weak physical condition with the effect of stimulation on the body's functions and adjustment of activities performed. Keep in mind that if giving excessive or too much massage will not raise the freshness of body as expected but can even make the patient become limp and sluggish. Otherwise, a massage that is too soft, it has less influence on physical health. While if the massage is too harsh in the emphasis it can lead to bruises or pain massage used [7].

Here are the various manipulations in Sport Massage used in this study [10]:

- Effleurage

- Petrisage

- Shaking

- Tapotement

- Friction

- Walken

- Vibration

- Skin-rolling

- Stroking

Sport Massage is given after a game or exercise with the intention to relax muscles and joints that have worked hard, some of the benefits of Sport Massage are as follows [2]:

- Helps to remove the lactic acid pile.

- Helps the muscles in taking oxygen and nutrients faster so as to speed up the healing process.

- To release the tension or muscle stress caused by excess physical activity.

- Helps disassemble scar tissue that usually affects muscles, tendons and ligaments that affect performance.

- Helps improve the elasticity of the tissue.

Lactic acid is a product of carbohydrate metabolism without the use of oxygen (anaerobic metabolism). Lactic acid is produced in muscle cells when oxygen supply is insufficient to support energy products. Lactic acid is the conversion of pyruvic acid when performing rapid physical activity. Lactic acid that formed and builds up in the muscle causes the cell to become acidic which affects inefficient muscle work, muscle pain and muscle fatigue so it must be interspersed with rest [12].

Lactic acid present in the body after exercise will be partially removed through sweat or urine, and a small amount of lactic acid can be converted back into glycogen form in the liver. It should be disclosed that the formation of glycogen in the liver from lactic acid does not play a very important role in the reduction of lactic acid levels. The biggest reduction of lactic acid is by converting lactic acid 
into the blood. This can be done by the muscles, heart muscle, kidney or liver.

According to the classical concept about 20 percent of the lactate produced during exercise is oxidized to pyruvate and then dissolved into $\mathrm{CO}_{2}$ and $\mathrm{H}_{2} \mathrm{O}$, and the remaining lactate is taken by the liver and forms glucose, which can be converted into glycogen or delivered to the blood. The muscle can then utilize this glucose in its glycogenesis to restore its glycogen depot. Of these calculations, about 85 percent of lactate is converted into glycogen but its way through the liver [1].

Lactic acid is a weak acid. Normally, lactic acid formed in the body will be removed through the muscles, kidneys, and liver. When there is a disorder that interfere with the change in lactic acid it can happen excessive buildup in the body. This buildup causes acid-base balance disturbance in the body. This excessive lactic acid causes the disease of lactic acidosis syndrome. In this syndrome symptoms occur in the form of nausea, vomiting, abdominal pain, weight loss, weakness, respiratory disorders, liver function disorders, heart rhythm disturbances, hands feet become cold and blue. Many causes can cause lactic acidosis, including:

- Body tissue lack of oxygen, for the example due to heart failure, respiratory failure, severe anemia, major bleeding;

- Severe infection ie sepsis;

- Drugs (rare) such as paracetamol, antiseizure, alcohol, aspirin, and others;

- Congenital disorders

High levels of lactic acid can cause adverse effects such as:

- High concentrations of lactate lead to acidosis in and around the muscle cells.

- High levels of lactate will interfere with coordination.

- High lactate content increases the risk of injury.

- The creatine phosphate system is disrupted by high levels of lactate.

- Fat oxidation in high levels of lactic acid stagnates.

The formation of lactic acid can be known by running as far as 100 meters which produces anaerobic alactat energy system with time about 10 seconds, 400 meter which produce lactic anaerobic energy system with time about 60 seconds, to run
800 meter produce $50 \%$ aerobic and $50 \%$ anaerobic with a time range of 2 minutes, and marathon runs with a time range of about 2 hours plus that yields $98 \%$ aerobic and $2 \%$ anaerobic. Where to run 400 meters will be a way to get maximum lactic acid, with a record time of approximately one minute or about 60 seconds. In this study to increase the levels of lactic acid in the sample then the sample must perform a sprint 400 meter first. After doing sprint then sample can do recovery [4].

In this research used for active recovery is aquatic exercise method. While in recovery passiveusing sport massage method. At that time lactic acid that has been destroyed will be directed to the heart in line with the direction of blood circulation leading to the heart. In the liver lactic acid will dioxide into glucose, glucose will be brought back by blood to the muscle to be stored as energy reserves in the form of glycogen, so lactic acid will quickly descend and the body regains energy reserves from lactic acid oxidation results.

\section{MATERIALS AND METHODS}

The research method used is experimental method. The form of research design using "Pre-Test and Post Test Design" is the provision of pretest before treatment and post test after treatment. As for the free variable is sport massage and aquatic exercise while the dependent variable is the decrease in body lactic acid levels in the students of Ilmu Keolahragaan Study Programme at the Universitas Negeri Jakarta.

\section{A. Participant}

The population in this research is the students of Ilmu Keolahragaan Study Programme at the Universitas Negeri Jakarta, which amounts to 100 people.

Sampling technique in this research is by using purposive sampling [11]. Samples taken amounted to 20 people, with the following criteria:

- Willing to do research

- Comes at the time of research

- Aged 18-22 years.

- Have done the examination by the doctor before the exercise.

- Has no history of heart disease.

- Has no occasional seizure habit or bladder incontinence. 
- Willing to follow the study voluntarily, including in following the training program of the trainer who then did experiments with sports massage and aquatic exercise.

- Willing to check lactic acid levels

Drop out criteria:

- Does not meet any of the above requirements

- Not following the lactate acid test in the final test

- Stop during exercise and irregular in doing the exercise program

\section{B. Instrument}

The instrument used to collect data in this study is to make measurements of the variables contained in this study. In this study data is taken by:

- Taking lactic acid data before performing a 400 meter sprint (as a reference on after recovery or knowing lactic acid breaks).

- Taking lactic acid data after sprint 400 meters.

- Taking lactic acid data after performing the sport massage method.

- Taking lactic acid data after performing the aquatic exercise method.

With these instruments researchers can measure the decrease of body lactic acid in students before and after doing sports massage and aquatic exercise.

\section{RESULTS AND DISCUSSION}

Data collection was used as research data obtained from initial and final test of lactic acid concentration in blood, based on observations of the effects of sport massage method and aquatic exercise method on decreasing lactic acid levels. The data can be described as follows.

Description of data in this study include the mean, the highest value, the lowest value, the standard deviation, the standard error mean of each variable, the following data:

TABLE I. TABLE DESCRIPTIONS OF SPORT MASSAGE EFFECTS RESULTS ON LACTIC ACID REDUCTION

\begin{tabular}{|lc|c|}
\hline Lactic Acid Level & Pre-Test & Post-Test \\
\hline The highest value & $12.3 \mathrm{mmol} / \mathrm{L}$ & $1.1 \mathrm{mmol} / \mathrm{L}$ \\
The lowest value & $21.1 \mathrm{mmol} / \mathrm{L}$ & $1.6 \mathrm{mmol} / \mathrm{L}$ \\
Mean & $14.75 \mathrm{mmol} / \mathrm{L}$ & $1.37 \mathrm{mmol} / \mathrm{L}$ \\
Standart deviation & 2.75 & 0.17 \\
Standart error mean & 0.63 & 0.04 \\
\hline
\end{tabular}

The analysis result of the initial test and the final test of lactic acid content by using the recovery effect of sport massage obtained the average value $\left(\mathrm{M}_{\mathrm{D}}\right)=13.39$, standard deviation $\left(\mathrm{S}_{\mathrm{D}}\right)=2.69$ and standard error mean $\left(\mathrm{SE}_{\mathrm{MD}}\right)=0.62$, $\mathrm{t}$-value obtained $=21.597$. Then the result is tested with t-table at degrees of freedom $(\mathrm{dk})=\mathrm{n}-1=20-1=19$ with the level of trust $(\alpha)=0,05$ obtained critical value ttable $=2.093$. Thus the $\mathrm{t}$-value is greater than $\mathrm{t}$-table $(\mathrm{t}$-value $=21.597>\mathrm{t}$-table $=2.093)$. With the increase of lactic acid from resting lactic acid by $75 \%$ and showed a decrease in lactic acid content by $90 \%$ by using Sport Massage.

Based on the analysis of data can be concluded null hypothesis $\left(\mathrm{H}_{0}\right)$ rejected, work hypothesis $\left(\mathrm{H}_{1}\right)$ accepted, it means effect of recovery work of massage massage can decrease lactic acid level.

TABLE II. TABLE DESCRIPTIONS OF AQUATIC EVERCISEEFFECTS ON LACTIC ACID REDUCTION.

\begin{tabular}{|l|c|}
\hline Lactic Acid Level Pre-Test & Post-Test \\
\hline The highest value11.1mmol/L & $3.1 \mathrm{mmol} / \mathrm{L}$ \\
The lowest value $18.7 \mathrm{mmol} / \mathrm{L}$ & $5.3 \mathrm{mmol} / \mathrm{L}$ \\
Mean 14.19mmol/L & $4.42 \mathrm{mmol} / \mathrm{L}$ \\
Standart deviation2.22 & 0.65 \\
Standart error mean0.51 & 0.15 \\
\hline
\end{tabular}

The result of the analysis of the initial test and the final test of lactic acid content by using the effect of aquatic exercise recovery obtained the average value $\left(M_{D}\right)=9.775$, standard deviation $\left(S_{D}\right)=2.48$ and standard error mean $\left(\mathrm{SE}_{\mathrm{MD}}\right)=0.57$, the t-value obtained $=17.149$. Then the result is tested with $\mathrm{t}$ table at degrees of freedom $(\mathrm{dk})=\mathrm{n}-1=20-1=19$ with the level of trust $(\alpha)=0.05$ obtained critical value $\mathrm{t}$-table $=2.093$. Thus the $\mathrm{t}$-valueis greater than $\mathrm{t}$-table $(\mathrm{t}$-value $=17.149>\mathrm{t}$-table $=2.093)$. With the increase of lactic acid from resting lactic acid by $80 \%$ and showed a decrease in lactic acid content by $68 \%$ by using Aquatic Exercise.

Based on the data analysis, it can be concluded that the null hypothesis $\left(\mathrm{H}_{0}\right)$ is rejected, the working hypothesis $\left(\mathrm{H}_{1}\right)$ is accepted, it means that the effect of aquatic exercise recovery can decrease lactic acid level.

From the final test of lactic acid levels in the recovery group of sport massage and aquatic exercise obtained standard difference between two mean $\left(\mathrm{SEm}_{\mathrm{x}} \mathrm{m}_{\mathrm{y}}\right)=0.84, \mathrm{t}$-value obtained $=4.303$. Then the result of the calculation is tested with $t$ table at degrees of freedom $(\mathrm{dk})=(\mathrm{n} 1+\mathrm{n} 2)-2=$ $(20+20)-2=38$, and the level of trust $(\alpha)=0.05$ 
obtained t-table critical value 2.021 (t-value = 4.303> t-table $=2.021$ ).

Based on the results of the data analysis then $\mathrm{H}_{0}$ rejected and $\mathrm{H}_{1}$ accepted so it can be concluded that there is a significant difference between the recovery of sport massage and recovery aquatic exercise to decrease lactic acid levels where the effect of recovery sport massage work decreases lactic acid levels more than the recovery aquatic exercise on the students of Ilmu Keolahragaan Study Programme at theUniversitasNegeri Jakarta.

\section{CONCLUSIONS}

Based on the problems that have been proposed and supported by theoretical description, research data obtained, and analysis of data that has been done then it can be concluded that sport massage better than aquatic exercise to decrease body lactic acid levels in students of Ilmu Keolahragaan Study Program of the Universitas Negeri Jakarta.

\section{REFERENCES}

[1] Bishop, Phillip. The Journal of Strength and Conditioning Research, Recovery From Training: A Brief Review: Brief Review. Science Hub. 2008.

[2] Ali Satya Graha and Bambang Priyonoadi. "Firage massage therapy,” IEEE. Transl. Terapi Masase Frirage. Yogyakarta:
Faculty of Sport Science, Yogyakarta State University, 2008.

[3] Hudson, Zoe. Journal of Physical Therapy in Sport, Enhancing Recovery and Performance in Sport.Elsevier, Science Direct, 2006

[4] Hoff, Jan. The Journal of Strength and Conditioning Research, Increased Blood Lactate Level Deteriorates Running Economy in World Class Endurance athlete. Science Hub, 2016.

[5] J. Hemmings, Brian. Journal of Physical Therapy in Sport, Physiological, Psychological and Performance Effects of Massage Therapy in Sport: a Review of The Literature.Elsevier, Science Direct, 2001.

[6] Kagarfard, Mehdi. Archive of Physical Medicine and Rehabilitation, Effect of Aquatic Exercise Training on Fatique and Health - Related Quality of Life in Patient With Multiple Sclerosis. Elsevier, Science Direct, 2012.

[7] Moran, Ryan N. Journal of Complementary Therapies in Clinical Practice, The Effects of Massage on Acceleration and Sprint Performance in Track \& Field Athletes. Elsevier, Science Direct, 2018.

[8] Podlog, Leslie. Journal of Physical Therapy in Sport, A Review of Return to Sport Concern Following Injury Rehabilitation: Practitioner Strategies for Enhancing Recovery Outcomes. Elsevier, Science Direct, 2011.

[9] Prado. The Journal of Strength and Conditioning Research, Effects of Aquatics Exercise on Muscle Strength in Young and Elderly Adults: A Systematic Review and Meta-Analysis of Randomized Trials. Science Hub, 2016.

[10] Samsudin. "Massage therapy," IEEE. Transl. Terapi Massage. Jakarta: Prenada Media Group, 2011.

[11] Sugiyono.Qualitative Quantitative Research Methods. Bandung: CVAlfabeta, 2011.

[12] Wiarto, Giri. Physiological and Sports. Yogyakarta: GrahaIlmu, 2013. 